\title{
URBAN SPRAWL IN MALAYSIA: EVIDENCES FROM THREE LARGEST METROPOLITAN AREAS
}

\author{
Jamalunlaili Abdullah', Mohd. Zulhafid $z$ Yahaya, Mohd Zuwairi Mohd \\ Yunus, and Mohd Shakir Md Ali Safudin \\ Faculty of Architecture, Planning and Surveying \\ UNIVERSITI TEKNOLOGI MARA MALAYSIA
}

\begin{abstract}
Urban sprawl is a one of the most pressing issues confronting urban development in the developed as well as developing countries. Much research had been done on the trend of urban sprawl and its negative consequences in established cities in the United States, Europe and Australia. This paper analyzes the phenomenon in the three largest metropolitan areas in Malaysia, namely Kuala Lumpur, Penang and Johor Bharu Metropolitan Areas. Using population and land use as main variables, it argues that suburban expansion and the resulting urban sprawl has been occurring in these metropolitan areas since 1970 and has intensified since the late 1980s due to the rapid economic growth brought by industrialization. It calls for more sustainable approach in the planning and management of urban areas in Malaysia.
\end{abstract}

Keywords: Urban Sprawl, Metropolitan, Malaysia

\section{INTRODUCTION}

The topic of urban sprawl is one of the most pressing issues confronting the global urban world, Malaysia being no exception. Many researches have been conducted on this issue with almost all of them indicating that the problem is real and of great negative consequences. Early studies focused on cities of the United States which, due to post World War II economic boom, had abundant supply of land and a great dependence on private automobiles which led to a horizontal expansion of the cities. The term suburbanization came out of this process. Los Angeles, Houston and Atlanta conjure the image of the urban sprawl of American cities.

European cities, which tend to be more compact due to massive rebuilding of bombed out central cities, started to expand and began to follow the American trend of growing at the suburbs. Cities such as Madrid, Paris and

'Email: bota65@yahoo.com 
London started to experience the urban sprawl phenomenon and began to resemble the American urban expansion. Economic policies associated with Ronald Reagan and Margaret Thatcher, which favour the role of the private sector in urban development, are partly the reasons for this development.

Much research has been done on sprawl especially in the United States. Most American metropolises have experienced massive urban sprawl with Los Angeles and Atlanta considered as poster child of sprawl. In Europe, a study of 24 cities by the European Environmental Agency in 2006 found that in majority of them, the growth of built-up areas were higher than those of the population and in a couple of Italian cities, more than doubled the population growth.

Sprawl is an environmentally unsustainable form of urban growth since it is characterized by a situation whereby built-up area increases faster that the population growth. Lower density in new suburban areas is taking up much more land for a smaller number of population as shown by Burchell, et al. (2002) and Galster, et al. (2001). This inefficient urban growth requires more investment for new infrastructure, more travel, especially automobile travel, which consumes energy and pollutes the air, gobbles up farmland and green areas, and leads to the decline of inner city. Sprawl is monetarily, environmentally and socially destructive to the built and natural environment.

The phenomenon of urban sprawl can be observed in Malaysia as well, albeit at a later period. This paper seeks to prove that the same type of urban expansion. i.e. horizontally rather that vertically, more intensive at the suburbs than the city centre, and a departure of the traditional colonial urban form are happening in the country. By using examples of the three largest metropolitan areas, i.e., the Kuala Lumpur, Penang and Johor Bharu, it shows that sprawl is the current dominant trend of urban growth in the country.

\section{URBAN SPRAWL IN THREE LARGEST METROPOLITAN AREAS OF MALAYSIA}

Malaysia is an urbanized country since the census of 1991, which revealed that 51 percent of her population lived in urban areas. The figure currently stood at about 65 percent. The trend is a result of the paradigm shift of the national economy whereby the Manufacturing sector overtook Agriculture as the largest contributor to the nation's economy in 1987. Currently the manufacturing sector contributes almost half of the GDP. 
With the growth of the Manufacturing sector, the urban areas became a magnet for the migration of people seeking employment in the new engine growth of the economy. While many thought that most of these people would migrate to city centres, evidences have shown that actually it is the peripheral areas that have been growing faster, sometimes at the expense of the city centres. There are various factors that led to this phenomenon, some of which include the location of the factories in the suburban areas, zoning regulations, lower price of land at the outskirts, the opening up of new highways and townships, and the overt dependence of Malaysians on private automobiles. The inefficiency of the public transport, higher per capita income and the national car policy had encouraged greater car ownership rate among Malaysians.

This paper seeks to find evidence of urban sprawl in the three largest metropolitan areas in Malaysia, namely the Kuala Lumpur Metropolitan areas (KLMR), the Penang metropolitan Area (PMR), and the Johor Bharu Metropolitan Areas (JBMR). Each of these is the prime urban area for its respective zone, KLMR in the central region, PMR in the north and the JBMR in the south of the Peninsular. The main variables used to evaluate the urban sprawl phenomenon in these metropolitan areas are population growth, density and land use.

\section{Urban Sprawl in Kuala Lumpur Metropolitan Region (KLMR)}

The phenomenon of the rise of the suburbs as well as the urban sprawl is best illustrated by the trend in the KLMR, perhaps due to the fact that it is the largest metropolitan areas in the country and many new townships had sprung out outside of Kuala Lumpur city boundary.

As shown vividly by Table 1 and Figure 1, the dominance of Kuala Lumpur as the main urban centre of KLMR, at least in terms of population, has diminished over the three decades of 1970 to 2000 . In 1970, Kuala Lumpur commanded 48 percent of the total population in the KLMR; 30 years later its share had decreased to a mere 28 percent. During the same time, the share of Petaling District had increased from 14 percent to 24 percent. It was followed closely by Hulu Langat district.

In 1970, population size of Petaling district was only 40 percent of the size of Kuala Lumpur. By the year 2000, Petaling population size was 91 percent of Kuala Lumpur population. For Hulu Langat, the relative size of its population compared to that of Kuala Lumpur had increased tremendously from 19 percent to 66 percent during the same time period. The growth of Petaling 
District is due mainly to the rapid population growths in new townships such as Shah Alam, Subang Jaya and newer parts of Petaling Jaya, while that for Hulu Langat is due to the growth in Ampang, Kajang, Bangi and Semenyih.

The relative higher share of suburban districts population can be explained by higher average population growth rate experienced by these new growth centres. Average anmual growth rate for Hulu Langat at 8.20 percent was more than 10 folds of that for Kuala Lumpur (1.39 percent) in the period of 1991-2000. Despite its already large population size, Petaling District grew at a very rapid 7 percent per year, making the district as significant as Kuala Lumpur as the population centre of the KLMR. Surprisingly, the trend is not a very recent phenomenon, it had occurred as early as the early 1980s. If the trend persists, Petaling District would have a larger population than that of Federal Territory Kuala Lumpur by 2010.

Table 1: Population and Average Annual Growth Rate, Selangor and Kuala Lumpur, 1980-2000.

\begin{tabular}{|c|c|c|c|c|c|}
\hline $\begin{array}{l}\text { State and } \\
\text { District }\end{array}$ & \multicolumn{3}{|c|}{ Population } & $\begin{array}{l}\text { Average } \\
\text { Growth } \\
\end{array}$ & $\begin{array}{c}\text { Annual } \\
\text { Rate }\end{array}$ \\
\hline & 1980 & 1991 & 2000 & 1980-1991 & $1991-2000$ \\
\hline SELANGOR & $1,426,250$ & $2,297,159$ & $3,947,527$ & 4.33 & 6.02 \\
\hline Gombak & 166,059 & 352,649 & 553,410 & 6.85 & 5.01 \\
\hline Kelang & 279,349 & 406,994 & 648,918 & 3.42 & 5.18 \\
\hline Kuala Langat & 101,578 & 130,090 & 189,983 & 2.25 & 4.21 \\
\hline $\begin{array}{l}\text { Kuala } \\
\text { Selangor }\end{array}$ & 110,366 & 123,052 & 157,288 & 0.99 & 2.73 \\
\hline Petaling & 360,056 & 633,165 & $1,181,034$ & 5.13 & 6.93 \\
\hline $\begin{array}{l}\text { Sabak } \\
\text { Bernam }\end{array}$ & 103,261 & 99,824 & 110,713 & -0.31 & 1.15 \\
\hline Sepang & 46,025 & 54,671 & 97,896 & 1.56 & 6.47 \\
\hline Ulu Langat & 177,877 & 413,900 & 865,514 & 7.68 & 8.20 \\
\hline Ulu Selangor & 81,679 & 82,814 & 142,771 & 0.13 & 6.05 \\
\hline $\begin{array}{l}\text { W.P. KUALA } \\
\text { LUMPUR }\end{array}$ & 919,610 & $1,145,342$ & $1,297,526$ & 2.00 & $\mathrm{I} .39$ \\
\hline MALAYSIA & $13,136,109$ & $17,563,420$ & $22,202,614$ & 2.64 & 2.60 \\
\hline
\end{tabular}

(Source: Malaysia, Department of Statistic, 2000) 
Figure 4.2: The Percentage of Population Share in Study Area from 1970 - 2000

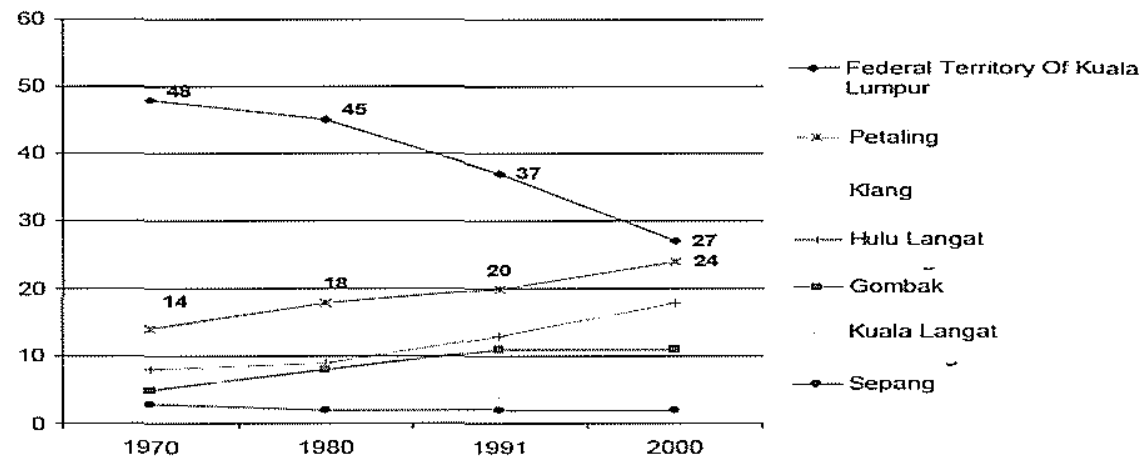

Source: Revised intercensal population estimates, Malaysia, $1957-1970$

Population Census of the Federation Of Malaya, 1957

Population and housing censuses of Malaysia, 1970 and 1980

Population and housing census of Malaysia 1980

General report of the population census, Malaysia, 1991

Figure 1: Share of KLMR Population by District, 1970-2000

(Source: Dept of Statistics, Population Census, 1970, 1980, 1991, 2000)

Figure 2 by Kuala Lumpur City Hall and Figure 3 by Ahris Yaakob illustrate the spatial built up of urban areas in KLMR pre and post 1991. The new built up areas after 1991 more than doubled the 1991 built up areas. New urban areas had sprouted after the construction of new highways, especially in areas leading to Putrajaya and Kuala Lumpur International Airport. While pre1991 growths tend to concentrate along the Federal Highway, the post-1991 urban growths are along the NKVE, LDP, ELITE and KESAS Highways. 

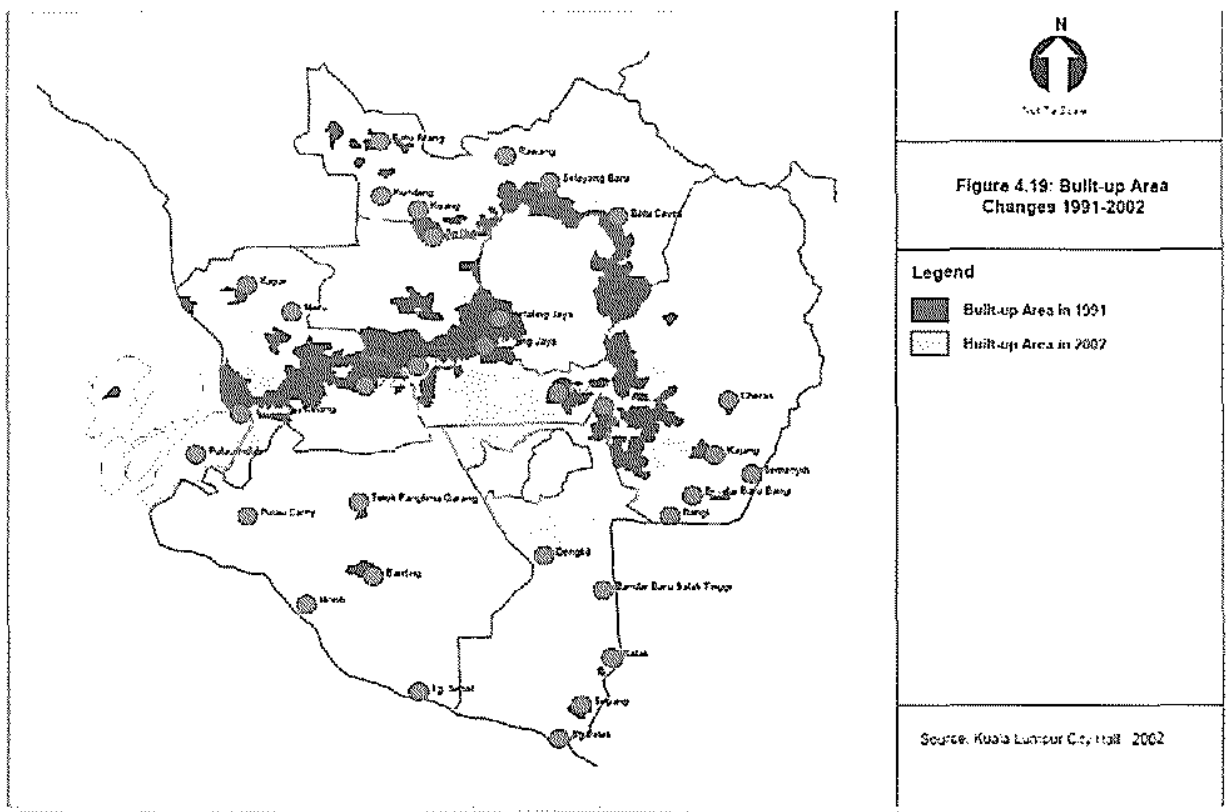

Figure 2: Built up areas in KLMR, 1991 - 2002

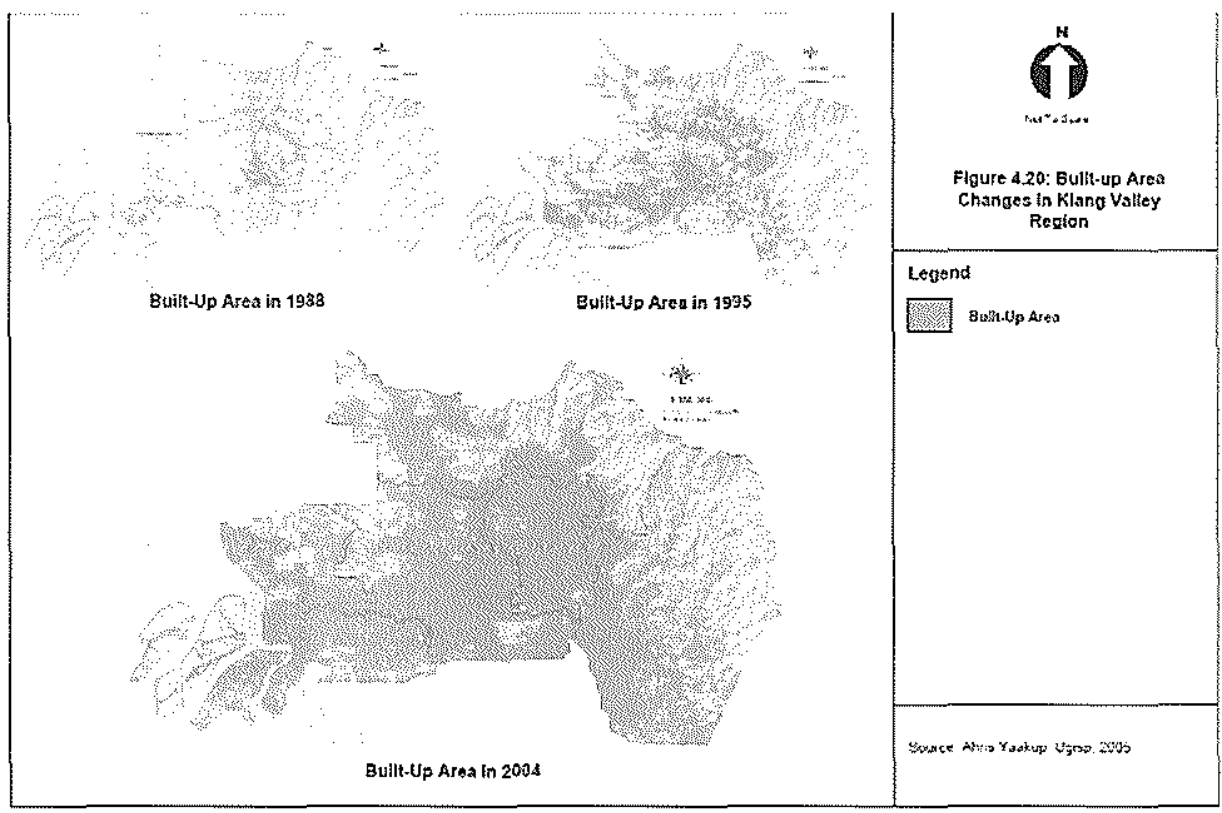

Figure 3: Built up Areas Changes in KLMR, 1988 -2004 


\section{Urban Sprawl in Penang Metropolitan Area (PMR)}

To the north of the peninsular, the same phenomenon of suburbanization and urban sprawl can be observed in the Penang Metropolitan Areas. Timor Laut District, in which the City of Goergetown is part of, accounted for almost half of the state population in 1970; by the year 2000, its percentage had dropped to only a third. On the other hand, district adjacent to Timor Laut, i.e. Barat Daya (Southwest) and Seberang Perai Tengah had increased their share of the population; the former by 5 percent while the latter by almost 9 percent. It should be noted that while Kuala Lumpur increased its population only marginally in the period of 1970 to 2000 , Georgetown actually had a population decline, i.e. its net out-migration figure was higher than its natural population increase.

This phenomenon is due to fact that districts other than Timor Laut had experienced high population growth rates between 1970 and 2000 (with the exception of Seberang Perai Utara). While the rate for Timor Laut had consistently been around 0.5 percent per annum since 1970, Seberang Perai Tengah grew by more than 3 percent per annum. In the 1980s, Seberang Perai Tengah and Barat Daya were the star performers, while the 1990s saw the emergence of Seberang Perai Selatan as the magnet of population growth in the state. Due to this, there was a population shift in the state. In 1970, a majority of the population in the state (55 percent) lived on the island; by the year 2000 , those on island became a minority ( 47 percent).

Urban expansion on the mainland is due to its land being cheaper than that on the island as well as the opening up of more land after the completion of the North South Highway and the Penang Bridge, allowing people to commute to places of employment in Georgetown. In addition, the growth of industry based townships such as Bayan Lepas in Barat Daya and Kulim in the 1980s and Batu Kawan in the south recently had led to many people settling around these new areas. The dominance of Georgetown as the main population and urban centre of the state is slowly disappearing. Unlike Kuala Lumpur which seemed to manage to hold to its attraction, due to its role as the nation's administrative and commercial centre of the country and redevelopment of the KLCC area, Georgetown does not seem to hold strongly to its dominance.

A worrying trend of urban growth in Penang state is the rate of new land being taken up compared to population growth. As Figure 5 indicates, in all the districts, with the exception of highly urbanized Timor Laut District, the rate of built up area growth was higher than that of the population. In newly opened up areas of Seberang Perai Selatan, the growth rate for the built-up area was more 
Samahnlaili Abdullah. Mohd. Zulhafidz Yahaya, Moht Zuwairi Mohd Yunts and Mohd Shakir Md Ali Safidin Urban Sprawl in Malaysia: Evidences from Thee Largest Metropolitan Areas

than double that of the population. The abundance of land in that district had led to inefficient use of land, a major characteristic of urban sprawl. If the trend continues, the implications to sustainable urban planning will be dire.

Table 2: Population and Percentage of State Population by District,

Penang State, $1970-2000$.

\begin{tabular}{|c|c|c|c|c|c|c|c|c|}
\hline \multirow{2}{*}{ Distrit: } & \multicolumn{2}{|c|}{1970} & \multicolumn{2}{|c|}{1980} & \multicolumn{2}{|c|}{1991} & \multicolumn{2}{|c|}{2000} \\
\hline & Population & $\%$ & Population & $\%$ & Population & $\%$ & Population & $\%$ \\
\hline $\begin{array}{c}\text { SP } \\
\text { Tengah }\end{array}$ & 117,475 & 15.19 & 161,975 & 17.98 & 236,270 & 22.20 & 294,051 & 23.88 \\
\hline $\begin{array}{c}\mathrm{SP} \\
\text { Utara }\end{array}$ & 161,524 & 20.89 & 199.449 & 22.14 & 224,647 & 21.11 & 243,938 & 19.81 \\
\hline $\begin{array}{c}\text { SP } \\
\text { Selatan }\end{array}$ & 63,626 & 8.23 & 71,558 & .7 .94 & 84.771 & 7.97 & 117,722 & 9.56 \\
\hline $\begin{array}{c}\text { Timor } \\
\text { Laut }\end{array}$ & $369.99 \mathrm{I}$ & 47.84 & 391,400 & 43.45 & 395,714 & 37,18 & 416,369 & 33.82 \\
\hline $\begin{array}{l}\text { Barat } \\
\text { Daya } \\
\end{array}$ & 60.711 & 7.85 & 76.390 & 8.49 & 122.764 & 11.54 & 159,129 & 12.93 \\
\hline $\begin{array}{l}\text { Penang } \\
\text { State }\end{array}$ & 773,327 & 100.00 & 900,772 & 100.00 & $1,064,166$ & 100.00 & $1,231,209$ & 100.00 \\
\hline
\end{tabular}

(Source: Department of Statistic, Malaysia, 2000)

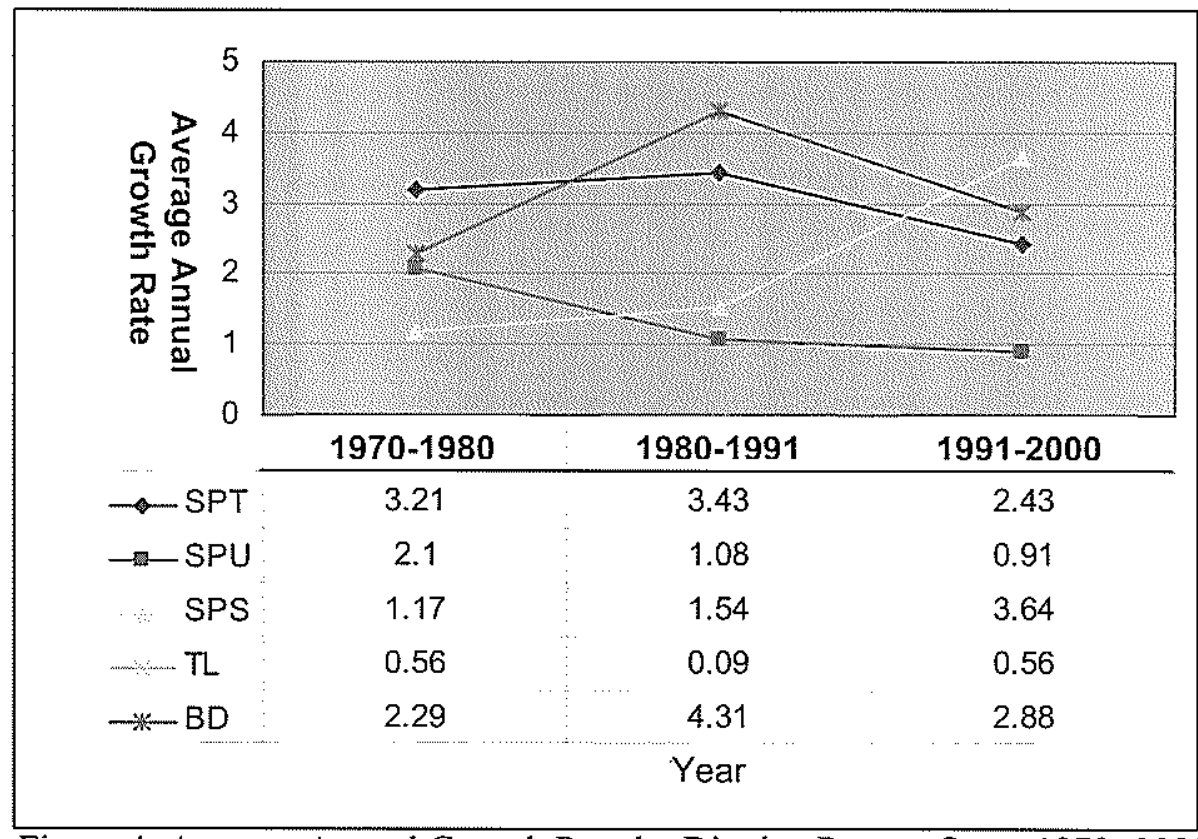

Figure 4: Average Annual Growth Rate by District, Penang State, 1970- 2000 (Source: Department of Statistic, Malaysia, 1970-2000) 


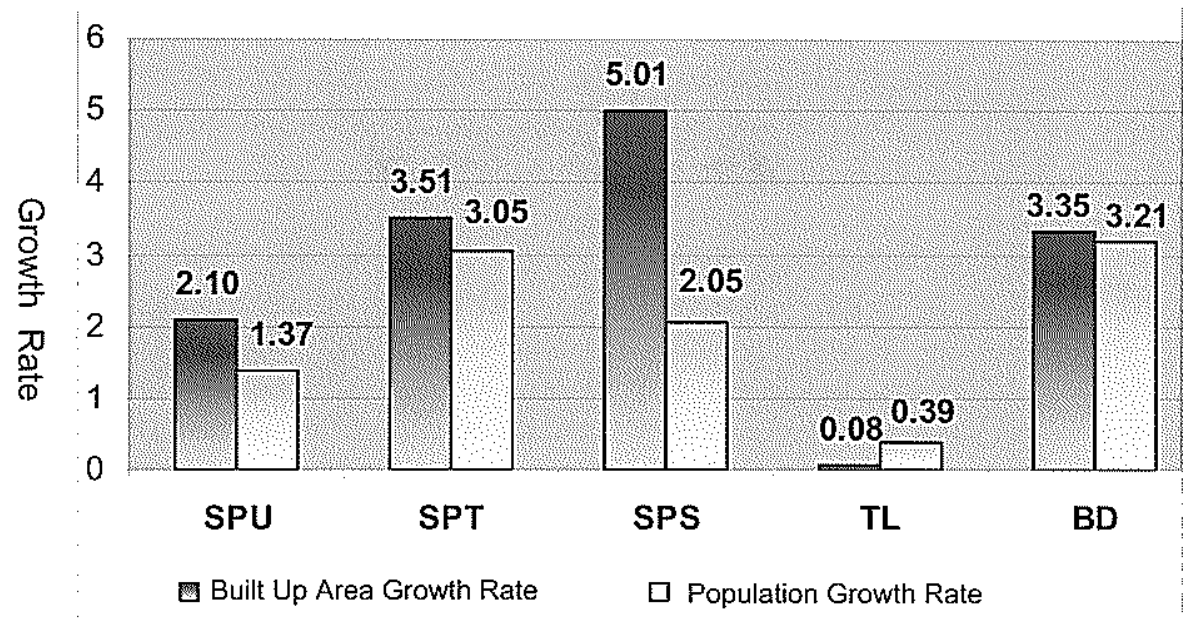

Figure 5: Growth Rates of Built up Areas and Population by District, Penang State, 1985-2000.

(Source: Laporan Pemeriksaan, Rancangan Struktur Negeri Pulau Pinang 2005 - 2020; Rancangan Struktur, MPSP, 1985; Rancangan Struktur MPPP, 1985)

\section{Urban Spawl in Johor Bharu Metropolitan Region}

To the south of the Peninsular, the Johor Bharu Metropolitan Area has been growing rapidly especially since the 1980s. During this period, Johor Bahru overtook Georgetown and Ipoh to become the second largest city in the country. However, a closer look at the trend reveals that most of the growth in this southern metropolitan occurred mostly outside the border of the city of Johor Bharu, the same trend as those in Kuala Lumpur and Penang metropolitan areas.

Unlike Georgetown which declined, and Kuala Lumpur which grew marginally since the 1970 , the city of Johor Bharu grew at a respectable rate of more than 2 percent per annum from 1970 till 2000. In the 1970s, it was the fastest growth municipality in the region, averaging almost 8 percent per annum. Thus, its population grew rapidly from 130,000 in 1970 to almost half a million in 2000.

Since the 1980s, however, rapid growth had shifted to the suburbs of Johor Bharu, mainly in Johor Bahru Tengah, where Skudai is located, and the Pasir Gudang area, one of the main industrial and port areas in the metropolis. The growth of Johor Bahru Tengah since the 1980 has been phenomenal. In 1980 , its population size was merely 6.5 percent of Johor Bharu City 
population; twenty years later its size was almost that of the city itself (90 percent of size of JB City). During the twenty years period, it grew at a whopping 15 percent per annum. Even the areas under the purview of Johor Bharu District Office, the most rural in the metropolitan areas, had been growing at respectable rates.

As in the other two metropolitan areas in central and northern regions of the peninsular, growth in the suburbs of JBMR is due to many large scale developments taking place outside the boundaries of the city. The building of Universiti Teknologi Malaysia and its surrounding township development as well as UDA new township had propelled urban growth in Johor Bahru Tengah. Growth of industries and the port in Pasir Gudang had shitted some development to the east of city; while to the west, the second link and new administrative township of Nusajaya will spur further rapid development.

In terms of density growth rate, JB tengah had the highest increase per annum in the 1990 s due to its rapid population growth rate. Population wise it grew at an astounding 2600 percent between 1970 to 2000 while Johor Bahru City grew by 192 percent. As a matter of fact, during the last three decades (until 2000), all three municipalities outside the city grew much faster than the City of Johor Bahru with Pasir Gudang registering absolute growth of almost 1500 percent.

\section{CONCLUSION}

This paper has shown the evidence of rapid urban growth at the suburban areas of main cities in the three largest metropolitan areas of the country. The reasons are due to the opening up of more lands outside city centres which tend to be cheaper, the heavy reliance on private automobile and the opening up of more highways. These factors go hand in hand in encouraging the expansion of built areas in previously green fields. While currently the impacts may not be significantly felt, if the trend persists, urban development in Malaysia will be very likely to be unsustainable.

The present trends of suburban growth will lead to the problem of urban sprawl with its host of negative elements. It leads to the decline of the city centre as evident in Georgetown, inefficient use of the land as shown in Seberang Perai Selatan (PMR), the loss of green areas which act as water catchment areas in Hulu Langat (in KLMR), and very rapid opening of green fields as illustrated in Johor Bahru. Opening up of more highways to ease congestion will only lead to greater reliance on private automobile which will 
lead to greater rate of urban sprawl. Kuala Lumpur has done rather well since the late 1990 s in arresting its slow population growth rate by offering rapid rail transit which led to new transit-oriented development strategies. Penang and johor Bharu may need to look at KL strategy.

Table 3: Population and Average Annual Growth Rates of Local Authorities, JBMA, 1970-2000

\begin{tabular}{|c|c|c|c|c|c|c|c|}
\hline \multirow[b]{2}{*}{ Local Authorities } & \multicolumn{4}{|c|}{ Populations } & \multicolumn{3}{|c|}{ Annual Growth Rates (\%) } \\
\hline & 1970 & 1980 & 1991 & 2000 & $1970-1980$ & $1980-1991$ & 1991.2000 \\
\hline Johor Bahn City Hall (VABJB) & 138,600 & 247.700 & 328.435 & 404780 & 5.81 & 2.56 & 2.32 \\
\hline $\begin{array}{l}\text { Johor Bahru Tengah Muncipal } \\
\text { Counci (WPJBT) }\end{array}$ & 13.357 & 16567 & 120.352 & 364.887 & 2.15 & 18.03 & 12.32 \\
\hline Kula City council (SIPKu) & $31.027^{*}$ & 47,067 & 70,237 & 113,171 & 379 & 364 & 53 \\
\hline $\begin{array}{l}\text { Pasi Gudang Local Authonty } \\
\text { (PBTPG) }\end{array}$ & 2,800 & 8,000 & 22.657 & 43,169 & 10.5 & 946 & 7.16 \\
\hline Johor Bahru District Office & $83.300^{\circ}$ & $87.537^{*}$ & 162.789 & 233,072 & 100 & 564 & 3.99 \\
\hline Total & 269.084 & 406,871 & 704,471 & $1,115,910$ & 4.13 & 39.33 & 31.09 \\
\hline
\end{tabular}

\begin{tabular}{|l|c|c|c|c|}
\hline \multicolumn{1}{|c|}{ Local Authorities } & \multicolumn{3}{|c|}{ Density Annual Growth Rates (\%) } & Absolute Growth Rate \\
& $1970-1980$ & $1980-1991$ & $1991-2000$ & $(1970-2000)(\%)$ \\
\hline $\begin{array}{l}\text { Johor Bahru City Council } \\
\text { (MiBJB) }\end{array}$ & 5.8 & 2.57 & 2.32 & 192 \\
\hline $\begin{array}{l}\text { Johor Bahru Tengah } \\
\text { Municipal Council (MPJBT) }\end{array}$ & 2.05 & 22.14 & 12.32 & 2627 \\
\hline Kulai City council (MPKu) & 6.73 & 3.63 & 5.29 & 265 \\
\hline $\begin{array}{l}\text { Pasir Gudang Local Authority } \\
\text { (PBTPG) }\end{array}$ & 10.66 & 9.48 & 7.18 & 1471 \\
\hline Johor Bahu District Office & 0.49 & 5.69 & 3.95 & 18 \\
\hline Johor Bahru & 7.28 & 7.16 & 5.55 & 651 \\
\hline
\end{tabular}

(Source: Statistic Department, 1980, 1991, 2000

JPBD, Report of Survey Johor Bharu, Mukim pelentong and pasir Gudang JPBD, Johor Bharu Local Plan 2020) 
The urban sprawl phenomenon in main urban areas in Malaysia requires planners and urban managers to look at alternatives to teh current trend and practices of urban planning. Rather than identifying only land available for development, planners should think a step further in guiding development to areas where sprawl can be contained more effectively. The relatively new concepts and stragies of Sequential Approach which is practiced in the United Kingdom and Smart Growth which has been in existence in the United States for the past two decades should be implemented in Malaysia. These strategies actively encourage mixed land uses, take advantage of compact building design, strengthen and direct development towards existing communities, preserve open space, farmland and critical environmental areas, provide a variety transportaion choices and foster distinctive, attractive communities with a strong sense of place.

Planners have to realize that the model that we have been following for the past decade, i.e. opening up of more land to meet demand, may need a paradigm shift in the new century. Land is scarce; efficient and effective management of existing urban areas through redevelopment and infill development rather than planning new layouts of green fields should be the new strategies of the day.

\section{REFERENCES:}

\section{Books/Journals:}

Burchell, R.W., et al., 2002. Transit Cooperative Research Program: Report 74, Washington D.C.: National Academy Press.

Department of Statistic Malaysia, 2000. Banci Penduduk dan Perumahan Malaysia 2000. Putrajaya. Jabatan Perangkaan Malaysia.

Department of Statistic Malaysia, 1991. Banci Penduduk dan Perumahan Malaysia 1991. Putrajaya. Jabatan Perangkaan Malaysia.

Department of Statistic Malaysia, 1980. Banci Penduduk dan Perumahan Malaysia 1980. Putrajaya. Jabatan Perangkaan Malaysia.

Department of Statistic Malaysia, 1970. Banci Penduduk dan Perumahan Malaysia 1970. Putrajaya. Jabatan Perangkaan Malaysia.

Department of Statistic Malaysia, 2000. Migrasi dan Taburan Penduduk 19952000. Putrajaya. Jabatan Perangkaan Malaysia.

European Environment Agency (2006), Urban Sprawl in Europe: The Ignored Challenge, European Commission Joint Research Centre.

Jabatan Perancangan Bandar dan Desa, 2000. Laporan Pemeriksaan Rancangan Struktur Negeri Pulau Pinang 2005-2020. Pulau Pinang. 
Jabatan Perancangan Bandar dan Desa Report of Survey Johor Bharu, Mukim Pelentong and Pasir Gudang

Jabatan Perancangan Bandar dan Desa, Johor Bharu Local Plan 2020

Jamalunlaili Abdullah, 2003. The Suburbanisation of The Kuala Lumpur Metropolitan Region. Planning Malaysia Joumal, Vol. 1, Malaysian Institute of Planners, pp. 119- 126

Majlis Perbandaran Seberang Perai, 1993. Rancangan Struktur 1993. Seberang Perai, Pulau Pinang.

Mohd Shakir bin Md Ali Safudin, Urban Sprawl and Expansion: Case Study of Johor Bharu. Unpublished Bachelor Urban and Regional Planning Thesis. Faculty of Architecture, Planning and Surveying, UiTM, Shah Alam, Selangor.

Mohd Zulhafdiz Yahaya, 2006. Urban Growth and Sprawl in Kuala Lumpur Metropolitan Region. Unpublished Bachelor Urban and Regional Planning Thesis. Faculty of Architecture, Planning and Surveying, UiTM, Shah Alam, Selangor

Mohd Zuwairi Mohd Yunus, 2006. Selerakan bandar: Kajian Kes Metropolitan Pulau Pinang. Unpublished Bachelor Urban and Regional Planning Thesis. Faculty of Architecture, Planning and Surveying, UiTM, Shah Alam, Selangor.

\section{Internet:}

Galster, George (2001). Wrestling Sprawl to teh Ground: Defining and Measuring an Elusive Concept. Retrieved 15 February 2009 from http://fanniemaefoundation.org/programs/hpd/pdf/HPD 1204 galster.pdf 
